\title{
Shifting of Batik Clothing Style as Response to Fashion Trends in Indonesia
}

\author{
Tyar Ratuannisa ${ }^{1}$, Imam Santosa ${ }^{2}$, Kahfiati Kahdar ${ }^{3}$, Achmad Syarief ${ }^{4}$ \\ ${ }^{1}$ Doctoral Study Program of Visual Arts and Design, Institut Teknologi Bandung, \\ Jl. Ganesa 10 Bandung, Indonesia \\ ${ }^{2,3,4}$ Faculty of Visual Arts and Design, Institut Teknologi Bandung, \\ Jl. Ganesa 10 Bandung, Indonesia. \\ ${ }^{1}$ tyar@fsrd.itb.ac.id
}

Fashion style refers to the way of wearing certain categories of clothing related to the concept of taste that refers to a person's preferences or tendencies towards a particular style. In Indonesia, clothing does not only function as a body covering but also as a person's style. One way is to use traditional cloth is by wearing batik. Batik clothing, which initially took the form of non -sewn cloth, such as a long cloth, became a sewn cloth like a sarong that functions as a subordinate, evolved with the changing fashion trends prevailing in Indonesia. At the beginning of the development of batik in Indonesia, in the $18^{\text {th }}$ century, batik as a women's main clothing was limited to the form of kain panjang and sarong. However, in the following century, the use of batik clothing became increasingly diverse as material for dresses, tunics, and blouses. This research uses a historical approach in observing batik fashion by utilizing documentation of fashion magazines and women's magazines in Indonesia. The change and diversity of batik clothing in Indonesian women's clothing styles are influenced by changes and developments in the role of Indonesian women themselves, ranging from those that are only doing domestic activities, but also going to school, and working in the public. However, fashion trend factors are also a parameter of change in batik clothing, which result in adaptive and flexible batik clothing.

Keywords: batik clothing, clothing style, fashion magazine, fashion trend

Proses Review : 1 - 20 Mei 2020, Dinyatakan Lolos: 26 Mei 2020 


\section{INTRODUCTION}

Clothing, especially those made from textile materials, is essentially made to cover and protect the human body from weather and other disturbances from outside the human body. In Indonesia, fashion is one of the cultural elements whose ownership and usage varies in each region in accordance with the plural concept of community thought (Hutabarat, 1999). Thus, clothing can represent the identity of the wearer. Fashion style refers to the way of wearing certain categories of clothing related to the concept of taste that refers to a person's preferences or tendencies towards a particular style. If the style is liked by a group of people in a particular social system, it will then become a fashion (King, 1980).

According to Hutabarat (1999), the regional attire that has been agreed upon, accepted, and worn by the majority of the people of Indonesia, which becomes a symbol of national culture, is called the national dress. One of the national clothing, according to Hutabarat, is a batik sarong that is used as a complement to the front clothing and front cover clothing for women. It is also used as a complement to the front opening clothes or close suit for men (Hutabarat, 1999). The use of batik sarong as a complement to fashion was found in various eras in Indonesia. Since the colonial era, the change in the style of batik sarong has been influenced by the popular fashion trends and closely related to other influential factors such as economic, political, social and cultural conditions.

This research seeks to describe the forms of change that occur through an analysis of visual content in the form of documentation of the use of batik sarong in fashion styles in Indonesia sourced from printed books on batik and some contents collected from print media of Indonesian women's magazines in the 1950 s to 2000 s. There has been no similar research found that investigated the same visual object regarding batik sarong in Indonesian fashion styles.

\section{Batik Clothing}

In terms of batik clothing type, there are two types of clothing that are most commonly used for bottoms, namely kain panjang (long cloth) and sarong. Kain panjang is a long rectangular shaped fabric with a width between 100$110 \mathrm{~cm}$ and a length of about $250 \mathrm{~cm}$. The sarong is a long rectangular sheath sewn on two sides so that it is tubular. Its width is the same as a long cloth but its length is shorter between 180-220 cm. Sarong is a typical Malay dress mainly used by inter-island traders and was widely known in Indonesia. Sarong has four forms, namely: a) made from silk or cotton; b) having chess or checkerboard pattern; c) decorated with gold tie and embroidery techniques; d) decorated with Javanese batik techniques. Sarong on batik has a wide stripe that runs perpendicular to a variety of decorative patterns, also known as heads (Veldhuisen, 1993). In 1872 , a statute was issued stating that all people living in Indonesia (formerly the Dutch East Indies) should wear clothing with their ethnic identity when leaving the house. Achjadi and Damais (2006) explained that, at that time, there were three major ethnic groups referred to in the statute, namely the Chinese or their descendants born in Indonesia (referred to as Sino-Indonesian), the Dutch, and Indonesians. Chinese men wore shan-ku, loose and wide trouser suits, side opening robes and pigtails dangling on the back (Achjadi and Damais, 2006). Chinese women wore front opening clothes called long dresses and batik sarongs. Around 1910, Dutch women who first wore typical European dresses began to follow the use of kebaya and batik sarongs as daily clothing. Indonesian women began wearing kebaya to cover their shoulders, which shifted from the habit of only wearing kemben.

The difference between Chinese, Dutch and Indonesian sarong was the characteristic of batik sarong used. Chinese women wore brightly colored sarong, each of which had a symbolic meaning. Dutch women wore sarong with colorful floral bouquets, folklore and exotic animals. Meanwhile, Indonesian women, especially those identified in Java, wore sarong with decorative colors according to their home village, with a gloomy color. Sarong was also referred to as one type of clothing that is commonly found in all walks of life. Sarong was used with a sling on the shoulder or used around the hips until the ankles covering the legs like a skirt (Raffles, 1817).

\section{Indonesian Women's' Fashion Style}

In Indonesia, fashion has been recorded since the discovery of yarn spinners used to make clothing. Making clothes was the fulfillment of clothing needs so that in the beginning it was only intended to cover the body. The known factor of religion and belief was a factor influencing how to dress and adornment since the 14th century as seen in the 2,600 Borobudur temple reliefs with a variety of clothing used in various activities such as farming, building houses, playing music and dancing (Anas, 2000). The development of fashion in Indonesia could then be traced back to the emergence of the politics of reciprocity or what was known as the Ethical Policy when Western education was implemented in Indonesia in 1900. At that time, there were many fashionable-looking women from various nations living in Indonesia.

Fashion trends in Indonesia in the 1930-1940 eras began to follow the pace of Western trends, with an international style that was young, relaxed and sporty. In addition, figures have begun to emerge in the world of fashion such as Maria Ulfah, Herawati Diah, Mien Soedarto and S.K. Trimurti (Zaman, 2002). Then, after the independence period in the early 1950 s, there had been a shift in the function of batik cloth for women's clothing, which had originally been bottom clothing changing into other forms such as tops or dresses, as found in articles in Puspa Wanita magazine. This modification continued into the next peri- 
od until the 2000s.

In the 1960s, Indonesian fashion was increasingly developed with the appearance of fashion designers and the birth of a department store as the first modern retailer in Indonesia, Sarinah. One of the factors supporting the development of the Indonesian fashion world in the 1970s was the emergence of Femina Magazine in 1972 as the only media in Indonesia that discussed fashion, founded by Pia Alisjahbana together with Mirtati Kartohadiprodjo and Widarti Gunawan. The orientation of Indonesian fashion at that time was international style and national clothing such as kebaya and sarong which were originally used for daily purposes shifting into traditional clothing that was used only for special purposes such as weddings, carnivals, or Kartini Day (Sunarya, 1999). The use of batik sarong was only found in certain segments of society. Until the decade of the 2000 s, precisely in 2009 , when batik was recognized as one of the World Intangible Heritage by UNESCO, the use of batik sarong was revived. The use of batik as a raw material for clothing was found not long after the use of batik as a sarong. However, the phenomenon of the emergence of awareness of the use of local raw materials such as batik for ready-to-wear clothing only revived after the recognition (Midiani, 2015).

\section{RESEARCH METHODS}

This research employed a qualitative approach with a historical method that presented data systematically based on time or diachronically. This method was also supported by the content analysis approach, a systematic technique for analyzing message content and message treatment, which is a tool for observing and analyzing the open communication behavior of certain message messengers (Budd, Thorpe and Donohew, 1967). The object analyzed in this research were printed images that contained information on the style of Indonesian women's clothing using batik sarong on their appearance in the print media of women's magazines, fashion magazines, and also website content with the same object. The object sources of analysis are:

Table 1. Object Source of Analysis

\begin{tabular}{lll} 
No. & Decade & Source \\
\hline 1. & $1800-1940$ & Literatures on batik \\
\hline 2. & $1950-2019$ & $\begin{array}{l}\text { Indonesian women's' fashion and } \\
\text { mode magazine: Puspa Wanita, } \\
\text { Femina and Dewi }\end{array}$ \\
\hline
\end{tabular}

\section{FINDINGS AND DISCUSSION}

Clothing as a cultural need encourages people to create clothing that is in accordance with the values and customs that live and develop in their communities so that the type
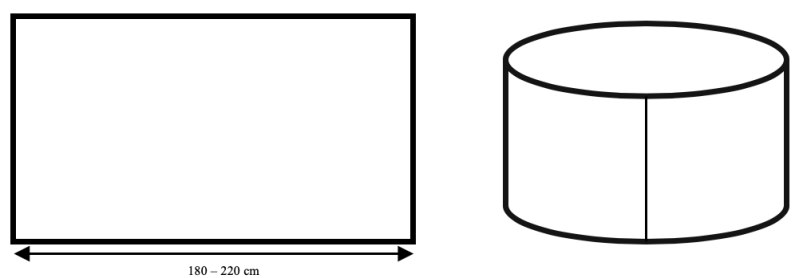

Figure 1. Kain panjang and sarong (illustrated by Tyar Ratuannisa, 2019)

of clothing changes according to changing times. In batik sarong, there are several aspects that can be investigated for changes. Visual objects are investigated based on the time difference:

At this pre-independence era or the colonial era time, the principle of sarong was a long cloth with both ends joined together as shown in the following figure:

The use of batik sarong was as a bottom with a kebaya top or worn directly on the chest in the form of blouse as shown in the following image:

Sarong, apart from being a dress for women outside the home, was also used inside the house or when doing activities at home. However, before entering the 20th century, most Indonesian women still carried out their activities at home, both in their own homes and in their master's house as servants or emben.

According to Zaman (2002), the turning point of Indonesian society's fashion style was during the ethical politics of 1900, which was marked by the appearance of fashionable women who came from parts of the world living in Indonesia. Their fashion style was different from the Dutch women in Indonesia, who followed the previous fashion style. Entering the 20th century, the Dutch began to pay attention to education in Indonesia. Indonesian women began many activities outside the home, such as for work and school which demanded a neat appearance.

Changes in the use of batik cloth and sarongs ranging from silhouettes, style, to their use as basic material for superiors' clothing were found in women's magazines in the 1950s, namely Puspa Wanita magazine.

The visual information on the Figure 4 shows the use of batik as a sarong, which was not only combined with a kebaya but also with a baju kurung from the Sumatra region. In the next visual information, on the same page and edition of the magazine, it was found that the use of batik cloth was mentioned as batik clothing (busana batik). At that time, Puspa Wanita magazine already had pattern drafting rubric that, according to Corsiglia (1971), had been developed around 1830 by Ellen and Ebenezer Butterick in the Metropolitan Monthly magazine (then called The Delineator). 


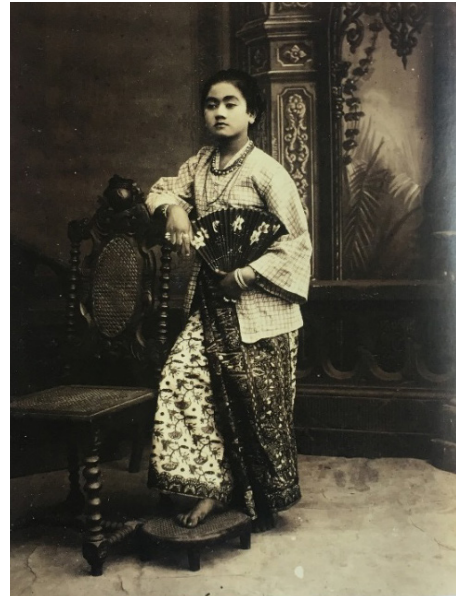

Figure 2. Sarong used by a servant around 1870 with kebaya as top (Smend, 2004)
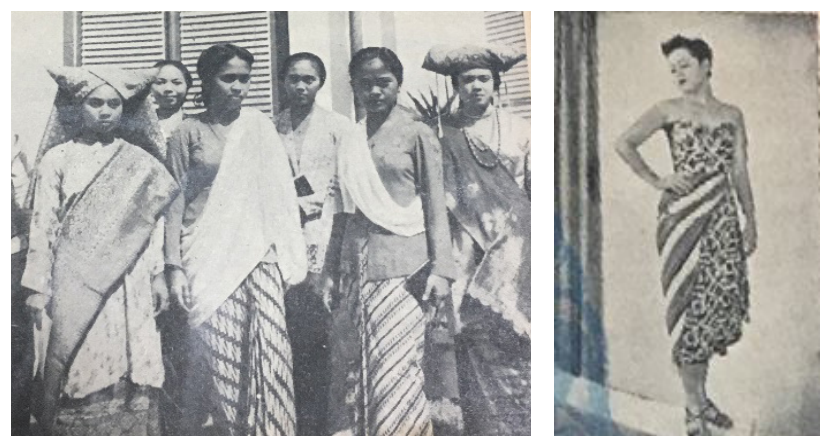

Figure 4. Pictures in one of Puspa Wanita magazine's edition on how to use batik cloth in two different ways

(Puspa Wanita, 1956)

One example was the pattern drafting of batik clothing for mothers and children, which in terms of silhouette and clothing construction did not resemble the clothes of Indonesian regions, but in the form of pieces of silhouette A dresses that were influenced by European women's clothing at that time. Regarding the influence of the dress, Zaman (2001) argued that this was a depiction of the romantic atmosphere of a cheerful young woman at that time, with dress pieces known as dirndl. This fashion style was influenced by the modern atmosphere of young people at that time that began to be influenced by jive, rock $\mathrm{n}$ roll, cha-cha and cha dancing activities.

In the following decades, the use of batik in clothing, both as bottom clothing with kebaya and as clothing material, was found in magazine content. However, it can be observed that batik clothes that match the kebaya were found in formal documentation or photography. In the Figure 6 there is a picture of a combination of batik sarong and kebaya worn by Indonesian women's competition finalists in 1986. Batik was previously considered as part of the craft. However, starting in the 1980s, batik was designed by fashion designers until its application was found in many fashion shows and craft and fashion exhibitions.

Meanwhile, in the next decade of the 1990s, printed batik textiles began to be widely known and used by design-

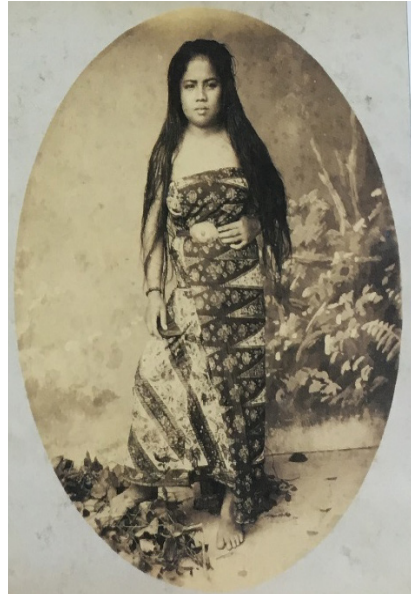

Figure 3. Sarong used on the chest like kemben (Smend, 2004)

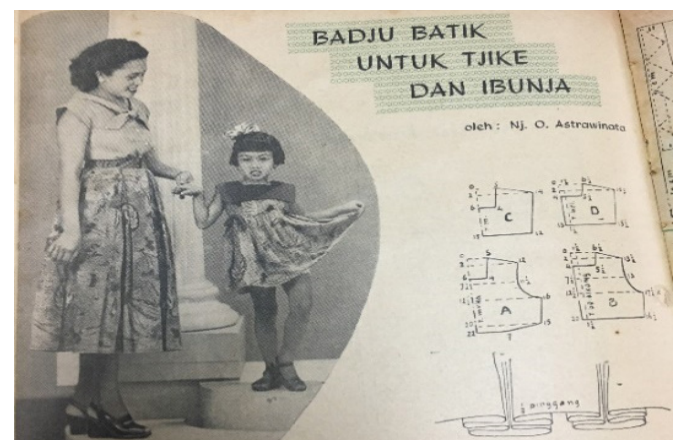

Figure 5. One of Puspa Wanita magazine's edition shows pattern for mothers and children clothes made of batik cloth

(Puspa Wanita, 1956)

ers. This made it easier for people to obtain and wear batik cloth. However, this also led to the interpretation that printed batik was batik cloth. Widespread awareness of the public about batik cloth was marked by UNESCO's recognition of batik cloth as the UNESCO Representative List of the Intangible Cultural Heritage of Humanity in 2009, which also started the commemoration of the National Batik Day on October 2 each year. In the same period, batik was revived again with the emergence of the trend of sustainable design. Batik was considered as one of the textiles which in some instances conformed to eco-fashion criteria, especially slow fashion and ethical fashion (Ratuannisa, 2016).

After the 2009 period, batik clothing that originally had a formal, traditional, and conservative image had changed into the modern, flexible and also casual ones. In terms of types or variations of clothing, it can be stated that there were no new types or variations of clothing when compared to the previous period. In the type of female tops, batik was usually used for blouses, tunics, or kebaya. In the types of female bottoms, batik was usually worn without stitches as a cloth with a wrap, a sarong, and a skirt. The difference was the increasingly diverse type of clothing pants such as culottes, harem pants to jogger pants. In the type of one piece, batik was usually worn as a canal or dress, with various silhouettes and pieces ranging from 
dress silhouette A, empire silhouette, Y silhouette and others.

Based on the data analysis, it can be concluded that the use of batik clothing in fashion in Indonesia is as follows:

Table 2. The shifting of Batik Fashion Style in Indonesia

\begin{tabular}{|c|c|c|c|}
\hline No & $\begin{array}{l}\text { Time } \\
\text { Period }\end{array}$ & $\begin{array}{l}\text { Fashion style } \\
\text { based on trend }\end{array}$ & Batik fashion style \\
\hline 1. & $1800-1940$ & $\begin{array}{l}\text { Clothing as a } \\
\text { basic function } \\
\text { or tradition in } \\
\text { Indonesia }\end{array}$ & $\begin{array}{l}\text { Kain panjang, } \\
\text { sarong as bottom } \\
\text { cloth, sarong as } \\
\text { kemben, shawl }\end{array}$ \\
\hline 2. & $1940-2000$ & $\begin{array}{l}\text { Fashion devel- } \\
\text { opment with } \\
\text { influence from } \\
\text { Dutch women's } \\
\text { fashion style with } \\
\text { practical and mod- } \\
\text { ern functions }\end{array}$ & $\begin{array}{l}\text { Kain panjang, } \\
\text { sarong, shawl, } \\
\text { dress, trousers and } \\
\text { blouse }\end{array}$ \\
\hline 3. & $2000-2019$ & $\begin{array}{l}\text { Modern clothing } \\
\text { with practical } \\
\text { functions was } \\
\text { more dominant, } \\
\text { but there are also } \\
\text { efforts to maintain } \\
\text { traditional cloth- } \\
\text { ing back in shape }\end{array}$ & $\begin{array}{l}\text { Kain panjang, } \\
\text { sarong as bottom } \\
\text { cloth, sarong as } \\
\text { kemben, shawl, } \\
\text { dress, trousers and } \\
\text { blouse }\end{array}$ \\
\hline
\end{tabular}

\section{CONCLUSIONS}

Indonesian women's clothing has a long history of development and has been influenced by various influences originating from outside Indonesia. This influence results in a variety of functions, shapes, silhouettes, and characters in Indonesian women's clothing. Batik as a traditional cloth is part of the development of Indonesian women's clothing, both as the main form of clothing in sarong without any variations or modifications to the original shape or batik cloth as a basic material in making clothes.

Changes in the function of batik cloth in Indonesian fashion style also represent changes in clothing needs for Indonesian women. In the period before ethical politics (1900), women worked more at home. However, after that time, Indonesian women began to do activities outside the home, both for work and education. In the following periods, Indonesian women's fashion styles have been increasingly developed along with technological developments in the production of textiles and clothing as well as information technology, which allows fashion trends in other parts of the world to influence fashion styles in Indonesia.
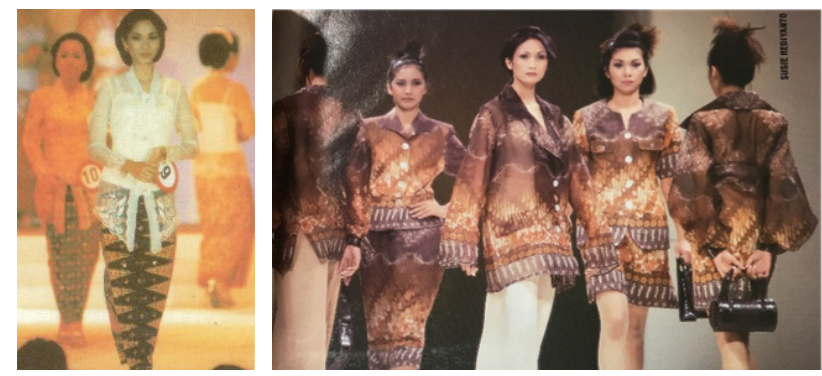

Figure 6. A combination of batik sarong and kebaya worn by Indonesian women's competition finalists in 1986 (left). Printed batik textiles used in fashion show event by designer, early 1990s (right). (Femina magazine 1985 and 1995 edition)

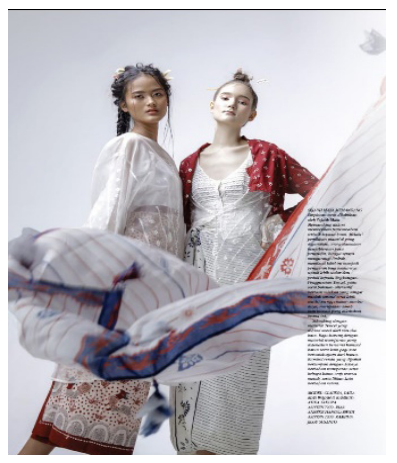

Figure 7. Batik cloth functionally returned to its root (see Figure 1 and 2), made by emerging designer, Chitra Subijakto for

Sejauh Mata Memandang brand (Dewi magazine, 2019)

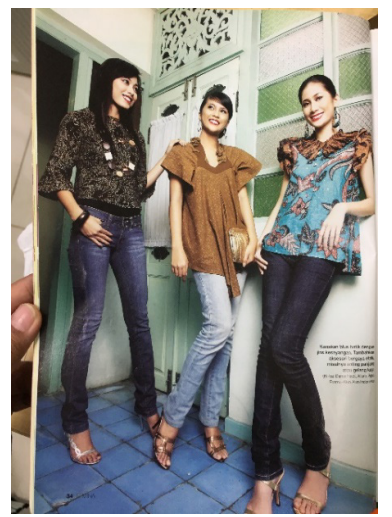

Figure 8. Batik cloth as material for blouse, Danar Hadi collection combined with pair of jeans showing its semi-casual image (Femina, 2004)

Changes in batik clothing in women's clothing styles in Indonesia also indicate the existence of the development of the batik industry and the fashion industry, which is now part of the creative industry that receives special attention from the government. Changes in world trends related to sustainable design, environmentally friendly design, and ethical to the natural environment and the human factors involved, encourage the recognition of batik as a traditional cloth by various groups in Indonesia. With the support of a variety of events related to fashion shows and exhibitions that elevate batik, it can be predicted that batik 
fashion will have a long future in the style of Indonesian women's clothing.

\section{RECOMMENDATION}

This research was part of research on changes in fashion styles in Indonesia from the perspective of fashion trends. The topic discussed in this article was a topic that can be developed and further explored by researchers. In the process of writing this article, the data of print media used were old data which at the time did not become a matter of special concern. However, in the future, as in this article, this can be an interesting research topic and deserves to be investigated from various aspects.

\section{CONTRIBUTION}

This article was part of the doctoral research of the first author, Tyar Ratuannisa, regarding the fashion trends model based on changes in fashion styles in Indonesia which are still ongoing. The author is a lecturer, researcher and practitioner in the field of textile crafts, especially traditional textiles. The second, third and fourth authors are promoters of the doctoral research process who have competencies in the fields of design and crafts.

\section{ACKNOWLEDGEMENTS}

Thank you to those who helped the authors during the process of preparing this article, especially those who helped in the acquisition of print media data for women and fashion magazines in Indonesia for years, namely the collectors and archives of the print media Archive Service of the Regional Library and Archives (Dipusipda, Dinas Perpustakaan dan Kearsipan Daerah) of West Java Province.

\section{REFERENCES}

Achjadi, J. \& Asmoro Damais. (2006). Butterflies and Phoenixes: Chinese Inspirations in Indonesian Textile Arts. Jakarta: Marshall Cavendish Editions.

Anas, B., et al.(1997). Indonesia Indah "Batik" Buku ke-8. Jakarta: Yayasan Harapan Kita, BP3 Taman Mini Indonesia Indah.

Corsiglia, R. B. (1971). A Content Analysis of Three Women's Magazines from 1960 to 1970 . Thesis. Faculty in Partial Fulfillment (Journalism and Mass Communications). Iowa State University.

Hutabarat, E.. (1999). Busana Nasional Indonesia Bekerjasama dengan Direktorat Jenderal Kebudayaan. Jakarta: Depdikbud.
King, C.W., dan Ring, L.J. (1980): The Dynamics of Style and Taste Adoption and Diffusion: Contributions From Fashion Theory. Advances in Consumer Research (Vol. 7).

Midiani, T.D., et al. (2015). Rencana Pengembangan Industri Mode Nasional 2015-2019. Jakarta: PT. Republik Solusi.

Raffles, S.T.S. (2008). The History of Java. Yogyakarta: Narasi.

Ratuannisa, T. (2016). The Adapted Ethical Fashion Trend in Indonesia's Tradition Based Modern Textile. In A. Prosiding The 5th Seminar on Nusantara Heritage: From Nusantara Heritage Toward South East Asia Heritage, p. 789-799.

Smend, R.G. et al. (2004). Batik: From The Courts of Java and Sumatra. Singapore: Periplus.

Zaman, M.A. (2001). 100 Tahun Mode di Indonesia 19012000. Jakarta: Meutia Cipta Sarana \& DPP Ikatan Busana Indonesia "Kartini".

Puspa Wanita, 1956 Edition. Courtesy of Archive Service of the Regional Library and Archives (Dipusipda, Dinas Perpustakaan dan Kearsipan Daerah) of West Java Province.

Femina, 1985, 1995 and 2004 representative editions, published by Femina Group. Collection of Tyar Ratuannisa.

Dewi, July 2019 representative editions, published by Femina Group. Collection of Tyar Ratuannisa. 